\title{
Wittgenstein e eu
}

\author{
João Vergílio Cuter
}

Professor da Universidade de São Paulo (USP)

Este texto foi originalmente apresentado como uma conferência. Será mantido nessa forma por motivos que não são acidentais, conforme o leitor poderá perceber. 


\section{Wittgenstein e eu}

Tenta-se especificar uma noção de "limite da linguagem" compatível com a filosofia madura de Wittgenstein. Essa noção é relacionada ao caráter necessariamente público dos critérios. Várias questões são feitas, então, quanto à possível existência de um objeto ou fato cuja identificação dependesse essencialmente de critérios privados. Essas questões revelam-se patentes contrassensos, e esse resultado mostra-se ontologicamente neutro. Assim, as questões filosóficas desaparecem, ao passo que o horizonte místico se mantém.

Palavras-chave: Wittgenstein, filosofia da linguagem, sujeito

\section{Wittgenstein and me}

An attempt is made at specifying a notion of "limit of language" compatible with Wittgenstein's late philosophy. This notion is related to the necessarily public character of criteria. Then a number of questions is raised as to the possible existence of an object or fact whose identification would essentially depend on private criteria. These questions are show to be sheer nonsense. This, by its turn, is shown to be an ontologically neutral result. So the philosophical questions disappear, while the mystical horizon remains.

Key words: Wittgenstein, philosophy of language, subject 
que tentarei fazer hoje, aqui, não é exatamente um exercício de exegese. Não apresentarei uma interpretação desta ou daquela passagem da filosofia madura de Wittgenstein, muito embora essa filosofia esteja no centro de minhas preocupações. Também não tentarei resolver algum problema específico colocado por essa filosofia. Como ficará claro, há um problema em torno do qual minhas reflexões estarão organizadas, mas esse problema diz respeito à filosofia de Wittgenstein como um todo, e a um modo possível, entre outros, de olhar para o conjunto. Esse modo de olhar é, se não me engano, perfeitamente neutro em relação às diversas interpretações possíveis dessa filosofia. Ele não pressupõe nada que não seja uma espécie de denominador comum entre os exegetas, e se acomoda, eu acho, bastante bem a correntes interpretativas muito diferentes. Apesar disso, não tenho dúvidas de que esse "modo de ver" proponho hoje seria recusado pela maioria dos intérpretes de Wittgenstein como absurdo e descabido. O curioso é que, de um certo ponto de vista, até mesmo a respeito disso eu concordaria com esses intérpretes, ao menos em parte. Paradoxalmente, muitas das coisas que falarei hoje deverão ser consideradas, por quem adota meu ponto de vista, como absurdas. Tenho esperança de que não sejam, apesar disso, completamente descabidas.

A ideia de que um discurso absurdo não seja, apesar disso, descabido, não é estranha a nenhum leitor do Tractatus. Como se sabe, o discurso articulado por Wittgenstein no Tractatus não pode ser considerado significativo por quem adota o ponto de vista a que o próprio livro nos conduz. Trata-se de um livro calculadamente escrito para provocar esse efeito no leitor. O Tractatus é um livro cujas sentenças 
pretendem ter uma dimensão exclusivamente perlocutória, num sentido especialíssimo do termo. Elas pretendem provocar no leitor efeitos que independam de qualquer coisa que seja, a seus próprios olhos, uma articulação de sentido. Melhor dizendo, provocam no leitor efeitos que dependem essencialmente de nossas reações psicológicas diante daquilo que aparece, de seu próprio ponto de vista, como mera aparência de sentido. É um discurso que não quer dizer nada, mas, apesar disso, produz efeitos, como aliás toda a metafísica tradicional sempre produziu. Sua pretensão é simplesmente produzir efeitos virtuosos, que nos conduzam não a proposições verdadeiras, mas a uma postura correta diante do mundo e da linguagem. A culminação desse processo é, como se sabe, um acesso silencioso à ordem atemporal e necessária inscrita na contingência da vida. Não há nada, portanto, de descabido nas pretensões perlocutórias do Tractatus. Seu discurso, apesar de absurdo, é perfeitamente cabível, já que está perfeitamente ajustado a um determinado fim.

O que farei hoje aqui não é exatamente isso. Até este momento, não pretendo ter dito nenhuma sentença que não faça sentido. Mais ainda, pretendo que tudo que eu disse até agora e que boa parte daquilo que irei dizer seja também verdadeiro - uma descrição verdadeira daquilo que uma determinada pessoa (Wittgenstein) pensou e escreveu, e de como outra pessoa (eu mesmo) foi afetada por esses pensamentos. Há toda uma parte do meu discurso, no entanto, que terá de se aproximar - perigosamente, confesso - da estratégia tractariana de romper os limites do sentido na tentativa de produzir efeitos. Foi a única maneira que encontrei de fazer uma proposta de leitura negligenciada entre os comentadores, e que me parece, apesar disso, a maneira mais rica e interessante de ler a obra madura de Wittgenstein. Por isso mesmo, achei cabível lançar mão dessa estratégia.

Darei, logo de saída, uma caracterização muito genérica dessa proposta, para em seguida desenvolvê-la no detalhe. As diversas leituras a que a filosofia madura de Wittgenstein se prestou têm, me parece, algo em comum: todas elas identificam um mesmo 
objetivo e um mesmo interlocutor. O interlocutor é o filósofo tradicional que, vitimado pela aceitação acrítica de uma certa concepção do sentido, é levado a postular a existência de entidades e processos, bem como a formular teses a respeito dessas entidades e processos que, quando devidamente analisadas, acabam se revelando não propriamente falsas, mas carentes de sentido. A mais típica dessas entidades postuladas é um "eu" que não coincidiria com o João Vergílio que todos vocês estão vendo, mas que só eu mesmo teria a possibilidade de acessar. $\mathrm{O}$ mais típico desses processos é o processo de atribuição de sentido aos sons que saem de minha boca ou que chegam aos meus ouvidos. A mais típica dessas teses é a que reúne esse "Eu dos eus" a esse processo de projeção do sentido sobre os sons da língua e resulta na afirmação da privacidade essencial da linguagem. O objetivo da filosofia de Wittgenstein seria, segundo as leituras correntes, demonstrar a falta de sentido envolvida nessas postulações e nessas teses, calando sistematicamente o interlocutor em cada uma de suas infindáveis tentativas.

Como eu já disse, não pretendo me contrapor a nenhuma dessas leituras - até porque, nesse nível de generalidade, concordo com todas elas. O interlocutor, de fato, está lá, como também estão lá suas postulações, suas teses e todas as manobras engenhosamente arquitetadas por Wittgenstein para desconstruir os edifícios verbais que esse interlocutor imaginário vai erigindo ao longo do texto. De certo modo, o objetivo de Wittgenstein é mesmo dar combate a esse interlocutor imaginário, no qual boa parte da filosofia moderna está contida em germe. A filosofia de Wittgenstein é transformada, por essa leitura, num evento acadêmico, universitário, endereçada a todos aqueles que, contaminados por um certo tipo de literatura, carecem de uma boa terapia para se libertar de uma espécie de feitiço. Não pretendo negar que a filosofia de Wittgenstein possa se transformar num evento desse tipo ou ser usada para esses fins. Como questão de fato, aliás, ela foi transformada exatamente nisso, e foi usada precisamente para esses fins. Para mim, porém, ela foi adquirindo outra 
dimensão, bem mais ampla e, na minha opinião, bem mais interessante. É sobre outra dimensão que eu gostaria de falar.

Eu gostaria de apresentar a filosofia madura de Wittgenstein como um exercício de ascese que conservou as pretensões místicas do Tractatus na medida em que estas puderam ser conservadas. A forma dessa filosofia não seria tanto um diálogo com um interlocutor externo, e sim um solilóquio. A terapia levada a efeito ali não teria por objetivo último desfazer mal-entendidos gerados no ambiente acadêmico, mas evocar esses mal-entendidos e dissolvê-los enquanto práticas linguísticas, condenando o autor da evocação a silenciar a respeito daquilo que ele, após o processo terapêutico, reconhece que não pode falar. Isso, porém, jamais é dito, nem poderia ser. Se fosse dito, deveria ser matéria para mais uma denúncia e oferecer uma nova oportunidade para o exercício reverente do silêncio. Mais que um evento acadêmico, a filosofia madura de Wittgenstein deveria ser vista como um chamamento à contemplação daquilo que a linguagem não pode dizer e que, quando tentamos dizer, acabamos inevitavelmente por profanar. A proposta de leitura que apresento neste texto é, sob diversos aspectos, uma profanação da qual, durante o debate, tentarei a todo custo me redimir. Vamos a ela.

Um bom começo seria tematizar a ideia de que a linguagem, para o segundo Wittgenstein, teria "limites" que não podem ser rompidos. Parece-me óbvio que toda a segunda filosofia dele é uma afirmação clara da existência desses limites, mas a palavra "limite" ficou tão associada à maneira tractariana de circunscrever o campo do dizível que essa obviedade, dita assim, sem rodeios, acaba assumindo o aspecto de uma heresia. É preciso, por isso, traçar com nitidez as distinções pertinentes. No Tractatus, a ideia de limite está associada à ideia de totalidade. A linguagem é a totalidade das situações possíveis no espaço lógico. Essa totalidade é dada, num primeiro plano, pela totalidade das proposições elementares e, num segundo plano, pela totalidade das funções de verdade daquelas proposições elementares. Ela é a mesma para toda 
e qualquer linguagem - e é por isso mesmo que Wittgenstein faz incidir sobre ela todo o peso que a palavra "pensamento" tinha na obra de Frege. Ela indica um estoque fixo de sentidos dados de uma vez por todas, uma espécie de "Biblioteca de Babel" onde estariam armazenadas todas as coisas que podem ser ditas, não importando em qual língua ou meio de expressão. A exibição desse estoque de sentidos é uma tarefa que caberia à análise lógica da linguagem, a ser feita pela posteridade nesse exercício singular que deveria, aos poucos, ir trazendo à tona a substância atemporal do mundo. Assim como para Berkeley cabia aos cientistas decodificar passo a passo, a gramática da linguagem com que Deus fala aos homens, para o Wittgenstein do Tractatus é aos lógicos que caberia essa tarefa de ir revelando o fundo de eternidade contra o qual a contingência do mundo está condenada a se apresentar. Ao trazer à tona a totalidade do espaço lógico, esses lógicos do futuro exibiriam os limites do dizível de maneira, digamos assim, positiva e individualizada: o que pode ser dito seriam precisamente essas possibilidades que a lógica, mediante uma trabalhosa análise, iria se tornando capaz de exibir.

Antes disso, no entanto, e permanecendo apenas nos limites daquilo que o próprio Tractatus nos legou, essa determinação já podia ser feita de forma negativa e genérica. O que é indizível, no Tractatus, é tudo aquilo que constitui uma condição de possibilidade do sentido. Querer descrever essas condições de possibilidade é inscrevê-las no domínio do dizível e na oposição entre o verdadeiro e o falso. Essa inserção pressupõe que o sentido dessas supostas descrições já nos fosse dado, e isso poria o carro das atribuições de verdade à frente dos bois da constituição do sentido. Proposições de essência seriam, no Tractatus, proposições que, para expressar o sentido que pretendemos que elas expressem, teriam que ser, antes de mais nada, verdadeiras. Examinemos como se daria este quiproquó lógico considerando a concepção tractariana de verdade.

Parece claro que o Tractatus adota uma concepção da verdade como correspondência, e é provável mesmo que tenha apresenta- 
do a mais radical e consequente variante dessa concepção em toda a história da filosofia. Para quem adota a concepção da verdade como correspondência, uma proposição é verdadeira caso ocorra, no mundo, o fato que corresponde a ela. A novidade da concepção tractariana de correspondência está no sentido preciso e radical que o Tractatus é capaz de emprestar ao verbo "corresponder" nesse contexto. Um estado de coisas "corresponde" à proposição elementar que o descreve caso cada um dos objetos que o compõe seja o significado de cada um dos nomes que compõem a proposição elementar. A concatenação de nomes, para ser verdadeira, deve encontrar, no mundo, uma concatenação correspondente de objetos: cada nome constante da proposição deve estar associado a um objeto categorialmente compatível no mundo.

O pressuposto de um isomorfismo categorial entre a linguagem e o mundo dá a essa concepção de verdade como correspondência seus tons mais característicos. A alternativa mais próxima desta, formulada dez anos mais tarde por Tarski, precisará recorrer à noção de metalinguagem, completamente estranha ao Tractatus, e à teoria dos conjuntos, que envolve aquela que é talvez a mais bizarra de todas as ontologias que a mente humana já foi capaz de conceber. O preço a ser pago pela concepção mais enxuta do Tractatus é duplo. Paga, em primeiro lugar, o preço de ser apenas uma promissória em branco, já que não apresenta um único caso de proposição elementar e deixa aos lógicos do futuro a ingrata tarefa de chegar a essa espécie de solo do sentido. No devido tempo, Wittgenstein reconheceria a definitiva impossibilidade de realizar essa tarefa. Em segundo lugar, paga o preço de ser indizível, já que a tentativa de descrever as relações entre a proposição elementar e o estado de coisas que a verifica deve passar necessariamente pela descrição das relações afigurantes entre os nomes constantes da proposição e os objetos componentes do estado de coisas.

Em alguns de meus artigos, tentei mostrar a situação paradoxal a que chegamos quando, assumindo o ponto de vista do Tractatus, 
tentamos descrever as relações afigurantes entre nomes e objetos. Darei aqui apenas os contornos gerais dessa situação. Descrições desse tipo deveriam dizer, por exemplo, que o nome "a" nomeia o objeto $a$. Nessa sentença de acabei de mencionar, tive que utilizar o nome "a" na última posição. Do ponto de vista do Tractatus, para que minha sentença tenha o sentido que eu pretendo que ela tenha, é necessário, antes de mais nada, que os nomes que a compõem designem os objetos que eu pretendo que eles designem. Em particular, o nome "a", que ocorre na última posição, deve designar o objeto $a$. Ou seja, para que minha proposição tenha sentido, é preciso que ela seja, antes de mais nada, verdadeira, o que é um absurdo. A verdade, do ponto de vista do Tractatus, só poderia ser dada concomitantemente ao sentido no caso das tautologias, que não descrevem coisa alguma e, por isso mesmo, não têm sentido nenhum. É a isso que me referi, mais acima, como a tentativa absurda de pôr o carro da atribuição da verdade à frente dos bois da constituição do sentido. Toda proposição de essência, para Wittgenstein, carregaria consigo esse ônus, e é isso que o levou a estabelecer a distinção entre aquilo que podemos dizer e aquilo que só podemos mostrar.

O sujeito tractariano está definitivamente posto no rol das coisas que só podem ser mostradas. Responsável pela instituição do sentido em seus diversos níveis, responsável pelo ato que institui um nome como nome de algo e pelos atos que operam sobre os sentidos elementares para formar sentidos logicamente mais complexos, o sujeito transcendental do Tractatus não faz parte do universo do dizível e deve ser concebido não como um fato no interior do mundo, ou como um objeto que possa aparecer nas concatenações de que o mundo é feito. O sujeito transcendental é, nas palavras do Tractatus, um "limite do mundo". Ele é parte das condições absolutas e indizíveis que circunscrevem o domínio do que pode ser dito e que, por isso mesmo, pode acontecer — ou não. O sujeito é um limite do mundo no mesmo sentido em que a totalidade dos objetos, a forma lógica dos objetos e as operações lógicas possíveis 
também o são. Ele é um pressuposto absolutamente necessário do sentido das proposições que dizem tudo aquilo que pode ser dito e, por isso mesmo, ele não se deixa descrever.

Esse é o sujeito da contemplação mística para a qual converge toda a filosofia do Tractatus. O mundo sub specie aeterni que esse sujeito contempla é a ordem atemporal dos objetos que determina o espaço lógico de possibilidades do qual o mundo dos fatos é um recorte fortuito. É a visão, por assim dizer, da possibilidade dos fatos, e não dos próprios fatos; é a visão de uma ordem imutável, dada de uma vez por todas, com absoluta necessidade, por trás de uma ordem mutável e contingente sobre a qual esse sujeito não tem poder algum. O mistério dessa presença é aquilo que o sujeito transcendental tem de visar para poder articular sentidos, mas é também aquilo que ele pode visar gratuitamente como algo absolutamente belo e absolutamente bom. É nessa ordem atemporal que o sujeito deve procurar uma beleza que não se reduz a uma sensação empírica de prazer, e um bem que não se esgota na economia dos castigos e recompensas.

A vontade empírica, no Tractatus, é parte do mundo - é um fato entre outros. É ela que me move até os fatos que parecem associados ao prazer e me distancia dos fatos que parecem associados à dor. Ela passa ao largo do exercício contemplativo que nos entrega, no próprio ato da busca, a Felicidade de estar em contato com a ordem imutável do ser. O mais miserável dos homens pode ter acesso a ela sem de seu mundo tenha que se alterar em qualquer um de seus aspectos contingentes. Continuará sendo pobre, passando fome, tendo dores, decepções, amargando derrotas, mas estará, nesses momentos de contemplação, fora da ordem temporal em que sua infelicidade se desenrola. Será Feliz, apesar de tudo que possa ocorrer ou deixar de ocorrer ao seu redor, e seu mundo será, num certo sentido, maior que o dos Infelizes, abandonados ao fluxo da contingência. Os fatos diante dele são os mesmos que se passariam diante de qualquer outra pessoa, mas eles se projetam contra um pano de fundo que 
lhes dá outra dimensão. Não creio que Wittgenstein tivesse qualquer objeção a chamar essa dimensão de "sagrada", se com esse termo quisermos apenas rotular o espanto diante da existência - espanto que está presente, das mais diversas formas, em toda e qualquer religião.

É claro que nada disso pode se manter na filosofia madura. Como eu já disse, falta a essa filosofia, antes de mais nada, a ideia de uma totalidade de sentidos que fornecessem o próprio objeto da contemplação mística. O sentido, na filosofia do segundo Wittgenstein, é dado por regras socialmente acordadas de uso de sinais, e essas regras nada têm de eterno ou imutável. Fazem parte do mesmo universo de convenções humanas em que estão as danças, as boas maneiras, os jogos de tabuleiro e as brincadeiras infantis. A linguagem e suas regras não são nem mais nem menos descritíveis do que as regras do xadrez ou os passos do bolero. Ao descrever as regras da linguagem, tenho de obedecê-las, ou não serei entendido. Mas não há nenhum problema profundo envolvido aqui. Para falarmos, temos que seguir regras. E uma das coisas a respeito das quais podemos falar são essas regras que devemos seguir quando falamos. Não há mais dificuldade em fazer isso do que em dançar falando sobre as regras que são seguidas por quem dança.

Longe de mim, portanto, sugerir que possamos recuperar, na filosofia madura de Wittgenstein, o tipo de experiência mística que, em sua primeira filosofia, estava associada à totalidade do sentido. Essa totalidade simplesmente se perdeu, e a linguagem, em vez de se contrapor ao mundo para descrevê-lo, passou a fazer parte dele, como uma das atividades regradas do universo humano. No entanto, gostaria de insistir sobre uma característica do misticismo do Tractatus que talvez possa ser reencontrada, sob outra roupagem, nas Investigações filosóficas. Refiro-me, aqui, a uma certa via de acesso à esfera mística. No Tractatus, ela estava essencialmente vinculada a uma interioridade inacessível à descrição - estava vinculada a essa fonte atemporal de atribuições de sentido que Wittgenstein identificava a um sujeito postado nos limites do mundo. A experiência mística 
consistia, ali, na assunção do ponto de vista desse sujeito. Contemplar a eternidade, como já vimos, nada mais é do que contemplar desinteressadamente a ordem eterna dos objetos e das formas, a partir da mesma perspectiva da qual projetamos nomes sobre objetos com a finalidade de articular sentidos. A contemplação aparece, então, como uma volta a essa interioridade originária e inefável, uma interioridade que não se confunde com a subjetividade empírica, que podemos perfeitamente descrever. O que tentarei mostrar é que algo semelhante subsiste, ou pelo menos é capaz de subsistir, na filosofia do segundo Wittgenstein. Para isso, devo mostrar primeiro algo que anunciei no início de minha conferência: a existência de uma condição de possibilidade do sentido no contexto das Investigações Filosóficas.

Como eu já disse, a identificação dessa condição de possibilidade não é algo que exige um grande esforço analítico. É algo que está logo na superfície do texto, e que não divide os comentadores. Na filosofia madura de Wittgenstein, a condição sine qua non do sentido é a publicidade dos critérios. Aliás, não apenas do sentido linguístico, mas de toda e qualquer regra. Não há regra desvinculada de critérios públicos de avaliação. Sem tais critérios, segundo Wittgenstein, perde-se a distância necessária entre a correção e sua aparência, e fica desfeita a possibilidade do engano, ou seja, daquela situação em que eu penso que estou fazendo a coisa certa mas não estou. É claro que, ao evidenciar essa relação essencial entre a regra e o engano, Wittgenstein não está fazendo outra coisa senão lembrar a relação gramatical entre a palavra "regra" e a palavra "engano". Dado o modo como usamos essas palavras, não faz sentido falar numa regra tal que seja logicamente impossível para uma pessoa enganar-se a respeito de sua aplicação. Onde há regra, há acerto e há erro, e há também o erro deliberado e o simples engano. Quem afirma que é logicamente possivel que alguém erre ou se engane durante uma dança não está, com isso, citando uma peculiaridade da dança, nem um traço característico da natureza humana. Está apenas citando uma peculiaridade de nosso uso das palavras "erro", "engano" e "dança”. Está 
dizendo, em última instância, que uma sentença como "O dançarino cometeu um erro" é uma sentença que pode ser usada no português para descrever um determinado tipo de situação.

Afirmar a existência de regras cujos critérios de aplicação são logicamente inacessíveis a um observador externo é, desse ponto de vista, uma contradição em termos. Se fosse logicamente impossível a outra pessoa avaliar se estou certo ou não, não faria sentido dizer que estou enganado. Não fazendo sentido dizer que estou enganado, não faz sentido também dizer que estou seguindo uma regra. Posso estar fazendo qualquer outra coisa, mas não aquilo que chamamos de "seguir uma regra". As exigências lógicas que fazemos à privacidade são incompatíveis com as exigências lógicas que fazemos às regras, e por isso, uma "regra privada" é, como acabei de dizer, uma contradição em termos. Por isso mesmo a exigência da publicidade dos critérios é, antes de mais nada, uma exigência gramatical. Ou os critérios são públicos, ou não é a respeito de regras que estamos falando. Pelo simples fato de estarem inseridas num sistema de regras, as sentenças da linguagem devem possuir critérios públicos de aplicação. Isso vale para todas elas: vale para as questões, para as preces, para as ordens, e vale também para as sentenças declarativas. Todos esses tipos de sentença são suscetíveis dos mais variados tipos de avaliação, e em toda avaliação haverá regras que, pelo simples fato de serem regras, exigem critérios públicos de avaliação. Questões podem ser pertinentes ou não, preces podem ser sinceras ou não, ordens podem ser oportunas ou não, e sentenças declarativas podem ser verdadeiras ou falsas. Cada uma dessas avaliações está aberta à possibilidade do erro e também à possibilidade do engano. Posso achar que uma pergunta pertinente, que uma prece sincera, que uma ordem oportuna ou que uma descrição é verdadeira sem que nada disso aconteça de fato. Em todos esses casos, terei me enganado: eu achava que estava certo, mas não estava. 
Há, no entanto, uma aparente exceção que ganhou fama e precisa ser enfrentada. Se digo que alguém está sentindo dores, posso estar mentindo de maneira deliberada, mas posso também estar apenas enganado. Pensei que alguém estivesse sentindo dores quando, na verdade, essa pessoa estava apenas fingindo. No meu próprio caso, porém, a possibilidade do engano está excluída: não faz sentido dizer que achei que sentia dores, mas que não eram dores o que eu sentia. As ocasiões especialíssimas que poderíamos imaginar para acomodar essa possibilidade não desfariam a diferença, mas apenas a detalhariam. É claro que um estrangeiro, por exemplo, pode enganar-se a respeito do uso da palavra "dor", como pode enganar-se a respeito do uso de qualquer palavra. Ele pode, por exemplo, dizer que está com dor quando, na verdade, está apenas indisposto. Ele pensava estar proferindo uma sentença verdadeira a respeito de suas sensações, mas não estava. Ele poderá dizer, então, que está sentindo dor, mas que, na verdade, não era dor o que ele sentia. No entanto, a referência à sensação, nesse caso, será apenas um modo indireto de se referir a um engano gramatical. $O$ engano que está excluído, no caso da dor, é de outra ordem. Quem acredita que uma haste mergulhada na água está quebrada engana-se, mas nem por isso está usando as palavras de um modo desviante. Desta maneira, e neste sentido, ninguém poderia enganar-se a respeito das próprias dores. A expressão do engano seria, nesse caso, um contrassenso.

O que estamos dizendo, porém, não seria exatamente o oposto do que dissemos um pouco mais acima? No caso da expressão da dor, em primeira pessoa, não estaríamos diante de uma regra a respeito de cuja aplicação seria impossível o engano? Creio que a resposta de Wittgenstein seria "não", e creio que as razões que ele daria para sua negativa seriam boas. Não posso me enganar a respeito do valor de verdade de minhas expressões de dor, assim como não posso me enganar a respeito da sinceridade de meus gritos. No meu próprio caso, está excluída a deliberação sobre o valor de verdade que a expressão de dor possui. Exatamente por isso, não há regra alguma que me 
diga como decidir se a minha expressão de dor é verdadeira ou não. Isso não quer dizer, porém, que não haja regras envolvendo o uso dessa expressão, ou que não haja regras para que os outros avaliem se minha expressão é verdadeira ou fingida. Pelo contrário. Quando expresso sinceramente a minha dor e quando finjo, devo levar essas regras em conta, e posso enganar-me a respeito delas. Posso, por exemplo, pensar que estou expressando minhas dores de modo convincente, sem que isso aconteça. Posso pensar que estou enganando o outro, sem estar. Onde há regras, o engano deve sempre ser possível.

Há um ponto importante a ser notado aqui. As regras que aprendi na infância para usar expressões de dor envolvem critérios públicos, e a identidade da sensação não é parte delas. Suponhamos que um gênio maligno tenha feito com que, desde o meu nascimento, a sensação de dor fosse substituída pela sensação de prazer, e vice-versa, mas que todas as minhas reações à dor - reações publicamente disponíveis - fossem reações de prazer, e que todas as minhas reações ao prazer fossem reações de dor. Sinto dores quando tomo vinho, demonstrando um prazer enorme naquilo. Busco essa dor deliberadamente, e procuro inclusive senti-la de maneira minuciosa, prestando atenção às suas nuanças. Expresso-me da mesma forma que todos, afirmando estar sentindo prazer, e afirmo isso com absoluta sinceridade. Quando sinto dores, porém, o que sinto na verdade são prazeres. Mas só o gênio maligno "sabe" disso, já que só ele é capaz de comparar a sensação específica que vê em mim com a sensação que vê nos outros. Ele é suficientemente ardiloso para trocar todas as reações cerebrais associadas aos dois sentimentos, de modo que nenhum tipo de exame clínico poderia denunciar a fraude. Em que sentido poderíamos dizer que estou "enganado"? O único ponto de vista a partir do qual meu engano poderia ser detectado é o ponto de vista do próprio gênio maligno. Mas é fácil de ver que este é um falso ponto de vista. Pois, que regras esse gênio poderia estar usando para fazer as afirmações que faz? E que garantias ele poderia ter de que não se engana ao identificar as minhas dores aos prazeres alheios? Mesmo supondo que ele tivesse 
acesso às sensações de cada indivíduo da mesma maneira que temos acesso às cores dos objetos, ele deveria ser capaz de identificar essas sensações da mesma maneira que nós identificamos as cores. Se ele tem uma linguagem para expressar essas identificações, deve poder enganar-se a respeito delas do mesmo modo que nós podemos nos enganar quando identificamos uma cor. Se ele tem regras para o uso de seu vocabulário de sensações, deve ter aprendido essas regras em situações públicas de uso, na comunidade dos gênios em que nasceu. Se for assim, o juízo da comunidade dos gênios poderia passar a fazer parte de nosso arsenal de identificação das sensações que temos em nós. Mas as regras seguidas por essa comunidade teriam, ainda assim, de ser públicas, e estar sujeitas à mesma oposição entre o acerto e o erro que encontramos em nossas próprias regras.

No limite, poderíamos imaginar a existência de um oráculo. Imaginemos que seus proferimentos sejam tidos como absolutamente verdadeiros e que ele seja considerado completamente imune ao erro. Se o oráculo dissesse que minhas sensações de prazer e de dor estão trocadas, eu deveria reconhecer que estava enganado ao dizer que sentia prazer ao tomar vinho. Quando tomar vinho novamente, poderei dizer, sem nenhum problema, que tenho a impressão de estar sentindo prazer, mas que na verdade o que sinto são dores. A inversão de minhas reações será admitida por todos e vista, provavelmente, como um tipo particularmente extremo de masoquismo. Nesse caso, porém, o próprio oráculo teria se transformado num critério para decidir se o que estou sentindo são mesmo dores, e os proferimentos desse oráculo seriam claramente tão públicos quanto meus gritos.

Regras são essencialmente públicas, assim como maçãs são essencialmente contáveis. Essa parece ser a lição que Wittgenstein está pretendendo nos transmitir ao longo de toda a sua obra madura. A ideia do Tractatus de que o sentido se articula solipsisticamente a partir da atividade de um sujeito posto nos limites do mundo é reduzida ao absurdo. Nas Investigações filosóficas, o sentido é reposto 
no universo mundano das regras, associado a reações humanas tão comezinhas quanto imitar o que os adultos fazem, ou olhar na direção daquilo que o dedo de um adulto aponta e não ficar hipnotizado pelo próprio dedo, como faria um gato. Longe de nos proporcionar um ponto de contato com o indizível, a linguagem é adquirida e exercitada (como a dança, os jogos de tabuleiro e as brincadeiras infantis) no plano daquilo que pode ser descrito, e a respeito do que nós podemos nos enganar, ou não.

Poderíamos tentar expressar esse caráter essencialmente público dos critérios na forma de um condicional. Diríamos, então, que, se existir algo que pertença a um domínio essencialmente privado, então nenhuma regra poderia usar esse "algo" como critério para suas aplicações. Essa constatação reflete-se de modo curioso em nosso discurso sobre aquilo que poderíamos chamar de "universo psicológico": o universo de nossos estados e processos mentais. As regras que regem esse discurso estão impedidas de usar aquilo a que esse discurso se refere como critério para a sua aplicação. É isso que dá a ele um estatuto sui generis e determina essa cisão entre a perspectiva da primeira pessoa, que está logicamente impedida de enganar-se a respeito das próprias dores, e a perspectiva de terceira pessoa, na qual o engano é possível. A privacidade dos estados e processos psicológicos aparece, por assim dizer, reproduzida na própria assimetria das regras e não pode ser expressa linguisticamente. A assimetria das regras apenas "reflete" a privacidade, sem descrevê-la. A sentença "sensações são privadas" é simplesmente a tradução de sentenças como "só eu posso saber que sinto dores", e sentenças desse último tipo ou são contrassensos (pois, como não faz sentido dizer que não sei se tenho dores, não pode fazer sentido afirmar que eu sei que as tenho), ou são enunciados oblíquos de regras gramaticais (quando respondo, por exemplo, à alegação de que eu talvez esteja enganado a respeito das dores que afirmo estar sentindo). Neste último caso, sentenças como "sensações são privadas" e "só eu posso saber se tenho dores" são comparáveis, como diz Wittgenstein, à afirmação de 
que paciência é um jogo que se joga sozinho. É uma regra de gramática, não a descrição de um fato.

Afirmar que o outro está tendo dores não é afirmar que ele está simplesmente tendo o comportamento de quem tem dor. Afinal, quem finge apresenta (ou tenta apresentar) os mesmos comportamentos. Descrições de estados e processos psicológicos são irredutíveis a descrições de processos corporais e de circunstâncias concomitantes. No entanto, os critérios para decidir se uma descrição psicológica está correta ou não, ou se ela é adequada ou não, devem ser procurados exatamente no plano desses processos e dessas circunstâncias. Esses critérios estão sempre no plano público, apartados por um fosso lógico do universo psicológico a que se referem, mas garantindo ao vocabulário psicológico um lugar na economia de nossas trocas linguísticas.

Suponhamos, agora, que haja algo que, ao contrário dos estados e processos psicológicos, só pudesse ser identificado por meio de critérios privados, algo que não tivesse ligação alguma com critérios públicos de identificação. Neste caso, estaríamos diante de algo que, por sua própria natureza, não poderia entrar na economia dos jogos de linguagem. Estaríamos, numa palavra, diante de algo que não pode ser dito. Se não me engano, é exatamente isso o que acontece com esse suposto "eu" que não se confunde com João Vergílio, esta pessoa que fala a vocês, comporta-se desta ou daquela maneira, e à qual vocês associam, com base em critérios públicos de identificação, uma série de processos e estados psicológicos. Refiro-me a esse "eu" que vive esses estados e passa por esses processos, e que a filosofia identificou quer a uma espécie de portador desses estados e processos, quer ao meio no qual esses estados e processos estariam ocorrendo, entendido como um âmbito especial de fenômenos, contraposto ao âmbito do mundo externo, das coisas extensas. Se esse "eu" portador de fenômenos ou esse "recinto pensante" existisse de fato, ele estaria completamente apartado de qualquer possibilidade de identificação por meio de critérios públicos, e não haveria como falar a respeito dele. 
Ocorrências e circunstâncias públicas seriam perfeitamente neutras com respeito à sua existência. Quando afirmamos que alguém sente dores - seja eu mesmo, seja outra pessoa -, afirmamos que um certo organismo humano vivo está exercendo uma de suas capacidades características: a capacidade de sentir dor. Temos critérios públicos para avaliar essa afirmação; todos eles dizem respeito ao comportamento desse organismo e às circunstâncias desse comportamento. No caso do comportamento alheio, tenho critérios para decidir se o que ele diz é verdadeiro ou não; se ele estiver dizendo algo falso, tenho critérios para decidir se ele está fingindo ou simplesmente não está empregando corretamente uma certa expressão. No meu próprio caso, eu posso expressar minhas dores, ocultá-las ou fingi-las, mas não posso saber que as tenho nem saber que estou fingindo, pois a expressão da dúvida está gramaticalmente excluída na primeira pessoa.

É a essa exclusão gramatical que podemos chamar, como já vimos, de "privacidade das sensações". Essa privacidade, porém, não determina um âmbito de fenômenos, mas apenas um âmbito de proferimentos - os proferimentos que expressam sensações na primeira pessoa do singular. A dor que eu sinto pertence exatamente ao mesmo âmbito que a dor que outra pessoa sente: o das sensações de que é suscetível um organismo humano vivo. Não existe um "eu", um "meio sui generis" envolvido nas sentenças que tematizam a dor, a não ser esse eu empírico possuidor de certas características físicas e psicológicas que vocês chamam de "João Vergílio", ou esse meio biológico a que todas essas características físicas e psicológicas estão associadas - um corpo humano vivo. São as reações desse corpo vivo e as circunstâncias que o cercam que nos permitem avaliar se aquilo que afirmo a respeito dele é verdadeiro ou não. Aquilo que gostaríamos de chamar de "conteúdo mental" (o besouro trancafiado em nossa caixa) e um suposto "eu profundo", escondido por trás dessas reações, se existem, não desempenham nenhum papel nesse processo. São, como diz Wittgenstein, "rodas girando em falso". Podem existir, ou não. O mecanismo linguístico como um todo se 
mantém inalterado. Nesse sentido, são linguisticamente inacessíveis. As proposições que tentam acessá-los ou são contrassensos, ou são asserções gramaticais disfarçadas.

Sob esse ponto de vista, o que a filosofia de Wittgenstein nos apresenta é, por um lado, um certo limite intransponível do sentido a publicidade necessária dos critérios. Por outro lado, ela nos põe diante de uma série de análises específicas, nas quais as tentativas filosóficas de ultrapassar esse limite são reduzidas ao absurdo, no sentido mais radical do termo. Essas análises não têm por objetivo estabelecer a falsidade das teses examinadas, mas sua carência de sentido, que se apresenta na forma de uma violação sistemática das regras públicas que regem a linguagem de que o discurso filosófico, como qualquer discurso, é obrigado a se valer. Procurei mostrar que essas análises não precisam ter aquilo que a filosofia tradicional chamaria de uma "contraparte ontológica" no sentido forte. Vistas de cima, o que elas estabelecem é uma certa limitação da linguagem, limitação que se exprime na exigência de critérios públicos para a avaliação das regras. Ela não se compromete com a inexistência de entidades que escapam à possibilidade de uma inserção na economia das trocas linguísticas, já que a expressão desse compromisso seria, do ponto de vista do próprio Wittgenstein, tão carente de sentido quando esta sentença que vocês estão ouvindo neste momento. A respeito de coisas que não podem ser ditas, nada pode ser dito, a começar por sua inefabilidade. O que podemos dizer, sem nenhum problema, é que, na tentativa de dizer algo, tal pessoa violou tais regras, da mesma maneira que poderíamos dizer que um jogador de xadrez, na tentativa de fazer uma jogada, violou tais e tais regras do jogo. Ao apontar o erro gramatical, reduzimos a tese ao silêncio, mas nada dizemos, nem poderíamos dizer, sobre a existência de entidades indizíveis. No máximo, convidamos o interlocutor a enfrentar essa existência de um modo perfeitamente legítimo e inobjetável: contemplando-a, sem nada dizer. É óbvio, no entanto, que esse convite também não pode ser feito. A palavra "contemplação" obedece, 
como todas as palavras da linguagem, a critérios públicos de aplicação, critérios que estariam, neste caso, ausentes desde o início. $\mathrm{O}$ que podemos contemplar é uma paisagem, e todas as paisagens que contemplamos outra pessoa também poderia contemplar.

Essas análises específicas da violação filosófica das regras gramaticais têm uma forma bem determinada. Um interlocutor imaginário é chamado, em primeiro lugar, para despertar no leitor uma certa inquietação filosófica com respeito a um certo âmbito de fatos. Os alvos preferenciais são o âmbito das vivências mentais e o das idealidades matemáticas. Em seguida, a análise de Wittgenstein incumbese de dissolver essa inquietação, reduzindo o interlocutor imaginário a uma espécie de quietude instável. A quietude é provocada pela evidência de que a pretensão discursiva do interlocutor estava assentada sobre violação de certas regras de uso das palavras de nossa linguagem. Ele afirma, por exemplo, que só ele pode saber se está sentindo dores, e é posto diante da evidência de que a negação da sentença "Eu sei que tenho dores" é um absurdo, pois não descreve situação alguma. A instabilidade dessa quietude, por outro lado, é provocada pelo fato de que o interlocutor procurava expressar algo a respeito do mundo, das coisas, e tudo que ele tem em mãos, após o processo terapêutico, é uma constatação a respeito das regras de nossa linguagem. Essa instabilidade, então, faz com que ele volte à carga, e tente mais uma vez exprimir aquilo que ele queria dizer antes, e não conseguiu. Novamente, a terapia irá reduzi-lo a uma quietude instável, que irá levá-lo a uma nova tentativa, e a uma nova frustração.

Essa articulação do texto faz com que o diálogo entre Wittgenstein e seu interlocutor repercuta em quem o lê como se fosse um solilóquio. O leitor deve sentir na própria pele a premência de uma certa questão, que parece recolocar a ontologia solipsista sobre uma base segura, e a cogência da resposta, que desfaz a pretensão à gramaticalidade da questão que acaba de ser feita. No final do processo terapêutico, o que se obtém é um silêncio atento aos limites da linguagem, que passa a ser exercida no domínio estrito das regras públicas 
de correção. Cessa com isso a angústia de falar daquilo que não pode ser dito, abrindo-se a possibilidade - mas só a possibilidade - de um contato silencioso com a matéria bruta da vida, essa aventura solitária que transcorre necessariamente atrás dos olhos e que linguagem nenhuma poderia ter a pretensão de descrever. É assim, pelo menos, que a terapia wittgensteiniana repercutiu em mim. Longe de me desviar disto que se costuma chamar de "mistério da existência", ela o magnificou, humilhando as pretensões da linguagem e deixando-me sozinho, sem discursos nem argumentos, diante de um espetáculo profundamente estranho e misterioso - a experiência, se se quiser, da existência do ser, ao invés do nada - que está na origem, se não me engano, de toda experiência mística autêntica. É claro que eu poderia tentar descrever essa experiência dizendo, por exemplo, que nesses momentos eu me sinto um ponto inextenso diante do infinito, ou coisas do gênero. Rapidamente, porém, eu me lembraria de que nada disso descreve coisa alguma, e que essa tentativa de expressão só me repõe no âmbito da diafonia insensata que, em vez de me aproximar da verdade, só consegue me distanciar do sentido. Retorno, então, ao silêncio, e devolvo a linguagem ao universo público no qual ela nasceu e para o qual ela foi criada.

Não há necessidade de que a filosofia de Wittgenstein tenha esse efeito sobre outra pessoa, mas acho importante salientar duas coisas, à guisa de conclusão. Em primeiro lugar, gostaria de reafirmar que ela pode ter esse resultado, e que não há nada nela que esteja em desacordo com esse efeito perlocutório do texto. Pelo contrário, há boas razões para pensarmos que os textos do segundo período são calculadamente escritos para provocar esse efeito. Em segundo lugar, quero lembrar que há boas razões para pensarmos que esta era a perspectiva a partir da qual o próprio Wittgenstein via a sua própria filosofia. A alternativa é uma postura naturalista indiferente aos apelos disto que poderíamos chamar de "mistério do mundo", uma postura diante da qual as religiões, por exemplo, não podem parecer outra coisa senão um exercício pueril da linguagem, que só 
pode interessar seriamente aos que se preocupam em analisar fenômenos de catarse coletiva, e coisas do gênero. Mas isso naturalmente não quer dizer nada, já que as atitudes assumidas por um autor em sua vida podem estar completamente desvinculadas de tudo aquilo que ele afirmou em seus textos. É bem verdade que há um famoso prefácio em que Wittgenstein afirma que dedicaria seu livro à maior glória de Deus, não fossem os mal-entendidos que uma dedicatória desse tipo poderia provocar numa época decadente como a nossa. Esse prefácio, porém, jamais foi publicado e, mesmo que o fosse, teríamos de admitir, como bons wittgensteinianos, que essa afirmação de Wittgenstein não faz o menor sentido. 
